\title{
Application of the Theory of Planned Behaviour Model for Examining Customers' Intentions towards Islamic Hire Purchase Financing
}

\author{
${ }^{1}$ Indus University, Block-17 \\ Gulshan, Karachi, Pakistan \\ E-mail.rizwanraheemahmed@gmail.com \\ ${ }^{2,3}$ Lithuanian Sports University \\ Sporto st. 6, Kaunas, Lithuania \\ E-mail. ${ }^{2} J o l i t a . V v e i n h a r d t @ g m a i l . c o m{ }^{3}$ Dalia.Streimikiene@lei.lt \\ ${ }^{4}$ Kaunas University of Technology \\ K. Donelaicio st. 73, 44249 Kaunas, Lithuania \\ *-corresponding author \\ E-mail.Vaida.Pilinkiene@ktu.lt \\ cross $^{\text {ref }}$ http://dx.doi.org/10.5755/j01.ee.30.2.21589
}

Rizwan Raheem Ahmed ${ }^{1}$, Jolita Vveinhardt ${ }^{2}$, Dalia Streimikiene ${ }^{3}$, Vaida Pilinkiene**

\begin{abstract}
The paper deals with the issues relevant to behavioural economics studies, demonstrating psychological and behavioural aspects of Muslim banking customers across the world. The aim of the research is to investigate the factors that are significant to customers using the Islamic hire purchase (auto financing) in Pakistan. The novelty of this study is to develop a modified model based on the Theory of Planned Behaviour (TPB) and apply it to bridge this gap as well as to identify the determinants. The TPB model was applied to examine the intention of customers buying automobiles through Islamic hire purchase financing. This study involves 730 respondents who are customers of Islamic hire purchase (IHP) from major Islamic banks of Pakistan. The results of the study demonstrated that the basic items of the TPB instrument, for instance, subjective norms, attitude, and perceived behavioural control, significantly influenced customers' intention to use Islamic hire purchase financing. At the same time, researchers assimilated three factors such as religious belief, pricing of Islamic banking products, and knowledge of Islamic banking products as moderating variables. The results verified their moderation and exhibited a significant link between items of the Theory of Planned Behaviour model and intention to use the Islamic hire purchase.
\end{abstract}

Keywords: Behavioural Economics; Customers' Intention; Theory of Planned Behaviour; Structural Equation Modelling; Islamic Hire Purchase.

\section{Introduction}

The Theory of Planned Behaviour is widely applied in behavioural economics studies dealing with customers' intentions and their drivers.

Islamic banking products follow the fundamental laws and principles of Islam in accordance with Shariah law. According to Dusuki and Abdullah (2007), Malaysian Islamic banks are more transparent with regard to the principles of Shariah law, however, the Islamic banking sector of Saudi Arabia, the UAE, Kuwait, Indonesia, Iran, Bahrain, Bangladesh, Qatar, and Pakistan also operates on the basis of Shariah law.

Based on literature, for example, Ali et al. (2017), Amin et al. (2014), and Haron et al. (1994), customers are attracted by Islamic hire purchase automobile financing due to religious faith and financial benefits. On the other hand, customers have shifted towards Islamic automobile financing due to compliance with Shariah law, financial cost, and social influence (Ali at al., 2017). Several previous research studies were conducted on customers' intention to use Islamic hire purchase (Dusuki \& Abdullah,
2007). It was identified that customers preferred to use Islamic hire purchase (IHP) due to such elements as religion, location, etc. According to Dusuki and Abdullah (2007), customers prefer IHP financing to conventional banking automobile financing due to financial benefits, religious beliefs and compliance with the basic principles of Shariah law. Numerous research data is available on the mixed outcomes regarding the usage of Islamic hire purchase financing (Metawa \& Almossawi, 1998). According to Ali et al. (2017) and Dusuki and Abdullah (2007), the attitude, perceived behavioural control, and the subjective norm are important determinants of buying behaviour related to Islamic bank financing. Bearing this fact in mind, customers' intention to use Islamic hire purchase has raised different dissimilar debates regarding the actual determinants of Islamic hire purchase. For instance, Amin et al. (2014) argued that this conflict regarding the true determinants of using Islamic hire purchase increased the importance of this research topic and promoted to carry out further scientific research in order to confirm more relevant and factual determinants of using IHP. 
The main problem is linked to finding out the main drivers of customers' intentions with the aim to increase of effectiveness of Islamic hire purchase financing. In Islamic countries, the conventional automobile banking is centred on the interest rate (Riba) that is strictly forbidden in Islam religion and contradicts to the basic Islamic principles (Shariah). Therefore, Islamic hire purchasing is the only solution for Islamic countries. Literature on customers' intention to use Islamic hire purchase (IHP) financing is very limited.

The novelty of this study is related to the development of the modified TPB model and its application for bridging this gap and identification of the determinants, which are important for using IHP financing in the case of the Islamic banking sector in Pakistan. This study is also imperative because in the Pakistani context, available literature on customers' intention to use Islamic hire purchase (IHP) financing is very limited. Although this study presents results and implications for Pakistan, its results can be widely applied to other Islamic countries as well. The modified TPB model and research methods can be used to analyze similar issues in other Islamic countries too. This study provides not only a substantial added value to current literature on the subject matter but also fundamental guidelines to the traditional and Islamic banking industry of Pakistan.

The study is related to the insights of behavioural economics and aims to analyze the impact of the dimensions of the TPB model and the influence of religious beliefs, knowledge of Islamic products, and pricing of Islamic products as moderating variables between the TPB model and the intention to use IHP financing.

The main objectives of the study: to analyze former literature; formulate a hypothesis; construct the modified TPB model providing the comprehensive approach enabling to examine customers' intentions towards IHP financing; carry out estimation and data analysis; discuss research results and provide managerial policy implications. Hence, considering the recommendation of this research study, marketers and senior managers will be able to devise their strategies to have a competitive advantage over other competitors.

\section{Literature Review}

\section{Theory of Planned Behaviour}

The fundamental model of the Theory of Planned Behaviour (TPB) was introduced by Ajzen (1991); this is an extension of the previously presented Theory of Reasoned Action (TRA) model, which was proposed by Ajzen and Fishbein (2000). Likewise, Ajzen (1991) in that continuity refined the previous model of the TRA, avoided the shortcomings of that model, and proposed that modified TPB model. On the one hand, the TPB model is associated with someone's belief and behaviour, and on the other hand, the TPB model has amplified the prognostic pre-eminence of the TRA model by incorporating a new dimension of perceived behavioural control (PBC). Thus, the new modified TPB model was comprised of three factors - attitude, subjective norms (SN), and perceived behavioural control (PBC) for an individual, filling the gap of the TRA model (Ajzen, 1991).

According to Ali et al. (2017) and Dusuki and Abdullah (2007), the TPB model is a much better predictor compared to any other theory model. This is due to the limitation of the TRA model, as it encompasses only two dimensions, i.e., subjective norms (SN) and attitude (Cismaru et al., 2017). The TPB model has an extra dimension of perceived behavioural control, which describes someone's belief and behaviour as well. Several research studies showed the significance and superiority of the TPB model over the TRA model (Ali et al., 2017; Shih \& Fang, 2004; Prapavessis et al., 2015; Ercsey, 2017; Gavurova et al., 2018). According to Shih and Fang (2004), perceived behavioural control (PBC) is described as someone's conduct because of perceived comfort and strain through coordinated behaviour. According to Ali et al. (2017) and Dusuki and Abdullah (2007), customers have control over their behaviour in order to make decisions regarding Islamic banking products.

\section{The Concept of Islamic Banking}

For the last few years, the concept of Islamic banking has been spreading very fast both worldwide and in the Muslim world. Islamic banking has introduced diverse products meeting investors' and customers' demands, encompassing both assets and liabilities. The list offering new Islamic financing products is evolving rapidly, responding to the needs of customers and market. Thus, Islamic finance provides a large number of feasible substitutes in accordance with the Islamic Shariah law compared to traditional banking. Islamic finance also provided financial products for equity markets, which triggered global financial integration amongst capital markets. This integration expanded inter-regional investment opportunities resulting in tremendous growth of financial markets across different regions of the world (Metawa \& Almossawi, 1998).

\section{The Concept of Islamic Hire Purchase}

The concept of Islamic hire purchase (IHP) is different compared to the conventional lease-purchase of the traditional banking system. The traditional banking system approves the loan for any desired vehicle keeping in view the individual's or organisation's financial position. The automobile will remain the property of the bank, and the customer will have to pay principal amount plus interest accrued for three or five years depending on the agreement. If any monthly payment is delayed, extra interest will be added to the agreed interest rate, thus, the customer has to pay a huge amount as interest. In Islamic hire purchase, on the contrary, the Islamic bank makes an arrangement to buy a car or any other vehicle for its customer and charge for rent of three or five years (depending on the agreement) with no penalty or any other extra payment in any circumstances. After the agreed rental time period, the same vehicle is offered to a similar customer to purchase at a nominal price (Metawa \& Almossawi, 1998). 


\section{Literature on Islamic Hire Purchase}

There is considerable amount of literature on Islamic hire purchase and studies have been conducted in Malaysia, Indonesia, Iran, Pakistan, Egypt, GCC countries, and other parts of the world. Islamic products created unitl 1994 include Ijarah (leasing) facility but Islamic hire purchase had not been fully developed yet. Consequently, the concept of Islamic hire purchase was formulated and the term Al-Ijarah-Thumma-Al-Bay (AITAB) was coined. According to Dusuki an Abdullah (2007), AITAB means to open a loop with lease, hire, rent and end with purchase and close the loop. Initially the bank buys the automobile and hands over to the customer on a monthly rent basis, and after five years, the same vehicle is sold to the customer at a token price or as a gift. The concept of Islamic hire purchase is based on two Islamic Shariah principles, the first-Ijarah (lease), and the second - Bay (sale) (Haron et al., 1994). Islamic hire purchase (AITAB) is not subject to any exclusive rules, law or regulation and is grounded on the traditional hire purchase Act adopted in Malaysia in 1967 (Dusuki \& Abdullah, 2007). However, Chong and Liu (2009) concluded in their research that there was no substantial difference between Islamic hire purchase and traditional hire purchase, but Naser et al. (1999) arrived at the conclusion in their study that Ijarah or Islamic hire purchase followed Shariah principles of Islam and had tremendous potential as a substitute for conventional hire purchase.

Several other studies were carried out on customers' satisfaction with respect to Islamic hire purchase; for instance, Ali et al. (1017) used 24 items questionnaire including the dimensions of the TPB model, which demonstrated positive results regarding Islamic hire purchase and customer satisfaction. Similarly, Naser et al. (1999) conducted a study on Jordanian customers and concluded that besides the religious belief, customers also maintained that Islamic finance products, including Islamic hire purchase, were high quality services. Haron et al. (1994) carried out an important study on Singaporean customers and concluded the same results that they used Islamic hire purchase because of religious belief and they thought this product followed Islamic Shariah principles. In the same vein, Haron et al. (1994) conducted an important study on Malaysian customers' perception and concluded that besides religious belief, the important factors for using Islamic hire purchase were economy or pricing. A significant finding of the research was customers' ignorance or dearth of knowledge about Islamic products, which shows that Islamic banks have insufficiently informed people about their financing products. According to Dusuki and Abdullah (2007), the Islamic hire purchase (AITAB) financing is based on two Arabic words that are grounded on Islamic Shariah principles.

There is not much available literature on Islamic hire purchase in Pakistan. Operations and customers' reaction towards Islamic hire purchase are highlighted by Ali et al. (2017), who have conducted their study on overall Islamic financing structure. They have also pointed out the factors for using Islamic hire purchase. Thus, the careful review of previous literature regarding Islamic hire purchase shows that there are hardly any specific research studies on customers' perception of Islamic hire purchase in Pakistan. The identified gap greatly motivates the authors to conduct the undertaken study.

\section{Formulation of Hypotheses}

After the thorough literature review, we formulated the following hypotheses, which are built on the dimensions of the TPB model and the impact of moderating variables such as pricing, knowledge of Islamic products, and religious belief.

\section{Perceived Behavioural Control and Intention to Use IHP}

Perceived behavioural control (PBC) is a significant dimension of the TPB model that explains one's behaviour towards decision making regarding buying behaviour. The TPB model introduced by Ajzen (1991) is an addition to another theory model, namely, the Theory of Reasoned Action (TRA) model. On the one hand, the TPB model is associated with someone's belief and behaviour, and on the other hand, it has amplified the prognostic pre-eminence of the TRA model due to incorporation of a new component PBC. Thus, PBC) has played a significant role in shaping customers' intention to use Islamic banking products (Dusuki \& Abdullah, 2007; Ali et al., 2017). Hence, the following hypothesis was formulated on the basis of previous literature:

$H_{1}$ : Perceived behavioural control (PBC) will have a positive influence on the intention to use Islamic hire purchase (IHP) financing.

\section{The Attitude and Intention to Use IHP}

The attitude is depicted as the individual's behaviour inclined towards the intention to use Islamic hire purchase (Shih \& Fang, 2004). The individual can analyze the efficiency and effectiveness of one's positive and negative tendency towards acceptance or rejection of any new product as a buyer (Ajzen \& Fishbein, 2000). According to Ajzen and Fishbein (2000), the attitude could be defined as the consumers' intention to use under their positive and unfavourable manner. A substantial amount of previous literature advocates the view that attitude is the main factor determining customers' intention to select or buy Islamic hire purchase or any other financing products. Ali et al. (2017) demonstrated that attitude was a significant factor exerting a cogent impact on consumers' intention. Similarly, Davis et al. (1989), Shih and Fang (2004) also demonstrated that attitude had a significant and positive influence on the customers' intention to use Islamic finance products. Hence, the following hypothesis was formulated on the basis of previous literature:

$\mathrm{H}_{2}$ : The attitude will have a positive influence on the intention to use Islamic hire purchase (IHP) financing.

\section{The Subjective Norm and the Intention to use IHP}

According to the TRA model, the subjective norm is also an important dimension affecting customers' intention to use the Islamic product. As identified by Ajzen (1991), the subjective norm is associated with societal stress or the 
social stimulus over the individual's perception regarding the intention to use some product. More specifically, the subjective norm is the influence of the individual or the referent groups of the community on the customer to decide whether he/she approves or disapproves the intention to use some specific product (Ajzen, 1991). The subjective norm is an important construct of the TPB and the TRA models, and it has a direct impact on the person's behaviour to accept or reject the product because of social pressure and influence on decision-making (Ali et al., 2017). The previous literature has illustrated mixed results; for instance, Chau and $\mathrm{Hu}$ (2001), Davis et al. (1989), Adamus (2017), Karbowski (2016) have demonstrated that the subjective norm neither makes nor exerts any cogent impact on customers' intent to buy some product. However, Ali et al. (2017), Dusuki and Abdullah (2007), Chan and Lu (2004) have concluded a significant and positive influence of the subjective norm on customers' intent to buy Islamic or other finance products. Similarly, Dusuki and Abdullah (2007) have demonstrated that the subjective norm has a cogent and positive effect on consumers' intention to use Islamic hire purchase (IHP). Hence, the following hypothesis was formulated on the basis of previous literature:

$H_{3}$ : The subjective norm (SN) will have a positive influence on the intention to use Islamic hire purchase (IHP) financing.

Moderating effect of religious belief, knowledge, and pricing of Islamic products and the intention to use Islamic hire purchase

We introduced three moderating variables, which substantiate the effects of TPB model constructs, i.e. , the subjective norm (SN), perceived behavioural control (PBC) and the attitude, and the intention to use Islamic hire purchase (automobile financing).

\section{Religious Belief}

In this study, we incorporated 'religious belief' that is an imperative element in Islamic automobile financing as a moderator, since in the conventional automobile financing, the interest rate is an integral part of conventional banking. According to Islamic principles, Riba (interest) is prohibited in Islam, thus, religious belief is the essential element for the customer choosing Islamic hire purchase. According to Dusuki and Abdullah (2007), religious belief is a significant component for customers selecting any Islamic finance product. Some other research studies also confirmed that religious belief was an important factor for Islamic banking and its products (Haron et al., 1994). Henceforth, it is believed that religious belief must have a significant effect as a moderator on Islamic hire purchase, and customers should have more intention to buy IHP. Hence, the following hypotheses were formulated on the basis of previous literature:

$H_{4 A}$ : Religious belief $(R B)$ will be a cogent moderator in the association of PBC dimension and the intention to use Islamic hire purchase (ITU);

$H_{4 B}$ : Religious belief $(R B)$ will be a cogent moderator in the association of the attitude dimension and the intention to use Islamic hire purchase (ITU);
$H_{4 C}$ : Religious belief $(R B)$ will be a cogent moderator in the association of the subjective norm dimension and the intention to use Islamic hire purchase (ITU).

\section{Knowledge of Islamic products (KIP)}

Knowledge of Islamic banking products (KIP) is also an important determinant influencing behaviour of any individual customer. Previous literature substantiates the fact that knowledge of the product enhances customers' intention to buy different consumer goods and services. Dusuki and Abdullah (2007) have used knowledge as a moderating variable between dimensions of the TPB model and the intention to use products. Results of all studies confirmed the influence of knowledge of Islamic products as a moderator between the TPB and the TRA models, and the intention to buy Islamic banking products. Haron et al. (1994) conceptualized knowledge as an external factor to assess consumers' awareness of Islamic banking products. Similarly, examining the customers' intention to use Islamic banking for different products, Dusuki and Abdullah (2007), and Gerrard and Cunningham (1997) put more emphasis on the consumers' behavioural model. They further investigated how knowledge of Islamic products enhanced the impact on consumers' buying behaviour. Hence, the following hypotheses were formulated on the basis of previous literature:

$H_{5 A}$ : Knowledge of Islamic banking products (KIP) will be a cogent moderator in the association of PBC dimension and the intention to use Islamic hire purchase (ITU);

$H_{5 B}$ : Knowledge of Islamic banking products (KIP) will be a cogent moderator in the association of the attitude dimension and the intention to use Islamic hire purchase (ITU);

$H_{5 c}$ : Knowledge of Islamic banking products (KIP) will be a cogent moderator in the association of the subjective norm dimension and the intention to use Islamic hire purchase (ITU).

\section{Pricing of Islamic Banking Products (PIP)}

We also incorporated pricing of Islamic products as a moderating variable in the undertaken study. Previous literature defined this construct as pricing of Islamic products, charged by Islamic banks (Ali et al., 2017). Islamic financing is based on profit and loss sharing (PLS), thus, devoid of interest rate (Riba), reduces pricing of Islamic banking products, which triggers the intention to use more Islamic products. A substantial amount of previous literature advocated the impact of pricing of Islamic products on customers' buying behaviour regarding Islamic financing products (Ali et al., 2017). Several research studies confirmed the impact of pricing of Islamic products as a moderator and concluded that pricing of Islamic products significantly increased the intention to use Islamic financing products (Tseng et al., 2011; Dusuki $\&$ Abdullah, 2007). Hence, considering the above discussions and previous literature, we formulated the following hypotheses:

$H_{6 A}$ : Pricing of Islamic banking products $(P I P)$ will be a moderator in the association of $P B C$ dimension and the 
intention to use Islamic hire purchase (ITU),

$H_{6 B}$ : Pricing of Islamic banking products $(P I P)$ will be a moderator in the association of the attitude dimension and the intention to use Islamic hire purchase (ITU);

$H_{6 C}$ : Pricing of Islamic banking products (PIP) will be a moderator in the association of the subjective norm dimension and the intention to use Islamic hire purchase (ITU).

Thus, based on previous literature and our proposed hypotheses, we developed the following modified conceptual model (Figure 1):

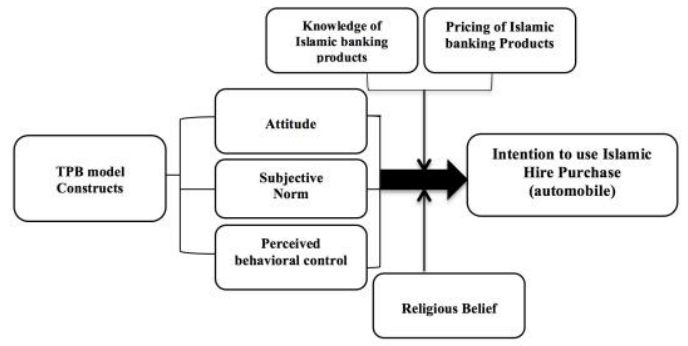

Figure 1. The Modified Conceptual Model of the Research Study

\section{Research Methodology}

\section{Data Collection}

We used seven hundred and thirty (730) responses out of 750 responses in total, of which 20 responses were poorly filled or incomplete. So, this way the response rate was $97.33 \%$, which is considered excellent; according to the guidelines of previous literature, this sample is considered a good sample (Anderson \& Gerbing, 1988).

In the undertaken research, we used the framework of the Theory of Planned Behaviour (TPB) model and the items of the TPB model to explain consumers' intention to use Islamic hire purchase (IHP) financing. The TPB model was efficaciously employed to explicate consumers' intention in several previous studies (Shih \& Fang, 2004; Ali et al., 2017; Novak et al., 2017; Varanavicius et al., 2017; Dusuki \& Abdullah, 2007; Akpinar et al., 2018). The main theoretical aspect of the TPB model links to fundamental postulations. Based on this evidence, Greve (2001) in his study said that there was a strong and direct connection among the individual's intention and action. This relation indicates that the intention is an essential part of any successful action. Also, Fishbein and Yzer (2003) continued their concern that comprehensive theoretical models were lacking recognition of human actions. Although, past research noted the TPB model is an effective theoretical model to describe behavioural intentions (Ajzen, 1991; Muthiah \& Suja, 2017). Therefore, this study also uses the TPB model in the perspective of IHP financing due to its general approval and poor implementation. Bilic (2005) stated that the TPB model had some shortages but its precursors were useful and were employed for practical measurements. This argument further explains that Islamic home financing behavioural intentions can be better explained and fully understood through the TPB framework. Therefore, it is assumed that the TPB is the essential component to know customers' behavioural intentions related to the Islamic home financing facility, which would further define the mechanism of actual behaviours for future studies (Wilkinson \& Abraham, 2004; Collins \& Ellickson, 2004). The limited numbers of research studies determined the intention to use Islamic banking products. However, none of the studies used Islamic hire purchase financing, thus, based on this explanation, the researchers were encouraged to conduct this research, and used the TPB model in order to investigate consumers' intention to buy Islamic hire purchase (IHP) financing facility, employing the case of Pakistani Islamic banking industry.

In this research, we used three constructs of the TPB model, introduced three moderating variables: pricing of Islamic products, religious belief and knowledge of Islamic products, and examined consumers' intention to use IHP. The constructs or items of the questionnaire were modified on the basis of existing literature according to the objective of this study. The construct of the attitude was taken and modified from research of Compeau and Higgins (1995). The construct of the subjective norm was adapted and modified by Ali et al. (2017). PBC is based on the studies of Shih and Fang (2004), Davis et al. (1989). Moderating variables were adapted and modified according to the items of studies by Dusuki and Abdullah (2007) on religious belief. Another important moderating variable we incorporated was pricing of Islamic products, taking the constructs from previous literature (Tseng et al., 2011). Finally, we used knowledge of Islamic products as a moderating factor, and items of the questionnaire were taken from the past research paper, namely, Dusuki and Abdullah (2007).

For data collection, we considered those respondents who either had already used the Islamic financing facility or intended to use that facility for Islamic hire purchase. We selected our sample from Karachi city. Data were collected using the purposive sampling technique; this method of sampling is reinforced by numerous previous studies conducted by Ali et al. (2017), Ahmed et al. (2016), Dusuki and Abdullah (2007). According to Ahmed et al. (2016), probability sampling has its own limitation and it would not represent the targeted population because every individual does not use IHP financing. It is also evident that the large sample, which was collected from either purposive or random technique that has the same characteristics of normality pattern and follows the central limit theorem, enables us to proceed with the same parametric statistical approach (Ahmed et al., 2017).

\section{Data analysis and Results}

\section{Descriptive Statistics}

According to Anderson \& Gerbing (1988), the collected data should follow the normality pattern, and it is a prerequisite for structural equation modelling and other SEM based multivariate statistical techniques. Thus, we converted all the responses into $\mathrm{Z}$ score, and the results of descriptive statistics showed that kurtosis values lay between \pm 3 , and skewness and standard deviation values were in the rage of \pm 1.5 , thus, this further proved that our data was following the normality pattern (Ahmed et al., 2017). 
Rizwan Raheem Ahmed, Jolita Vveinhardt, Dalia Streimikiene, Vaida Pilinkiene. Application of the Theory of Planned...

\section{Exploratory Factor Analysis}

The exploratory factor analysis was used to identify the suitability and reduction for the data sample; in fact, the analysis identifies the laden items that recruited on a similar constructor factor. Factor analysis technique has the capability to contract a large amount of sample data into a reduced form. The technique of factor analysis may help the researcher to examine the possessions of the variables (Ahmed et al., 2017). The undertaken study employed the principal component rotated matrix to authenticate the construct validity of items and factors. We incorporated seven factors, and for these seven factors, we incorporated 26 items. For PBC, attitude, SN, attitude, RB, and intention to use IHP we loaded four items for each factor. However, for knowledge of Islamic products (KIP), and pricing of Islamic products (PIP) we loaded three items for each factor. The outcomes of the principal component analysis showed that every set of variable and item had the value over 0.50 , thus, all the factors and items were validated and we could incorporate all items in the undertaken study (Kaiser, 1974).

\section{Total Variance Explained}

The dispersal of the variance amongst the prospective factors can be explicated by minimum cumulative variance; moreover, the variance amount could be established through Eigenvalues as well. The total values of Eigen should be greater or equal to 1.0. In our results, the minimum cumulative variance is 73.39 (73.39\%), which is considered very good, because the threshold value is over $50 \%$, moreover, the results of total Eigenvalue are also greater than 1.0. Thus, our minimum cumulative variance and Eigenvalues permitted to proceed with our analysis, and the data we collected is to be considered reliable.

\section{Kaiser Meyer Olkin (KMO) and Bartlett's Techniques}

The appropriateness of sampling could be assessed through KMO and Bartlett's Sphericity methods. The outcomes exhibited that the KMO value was 0.811 , which is considered very good, because the values ranging from 0.70-0.79 are to be taken as good (Kaiser, 1974). Similarly, the outcomes of Bartlett's Sphericity showed the probability of 0.000 that is less than 0.05 , which demonstrates that the correlation between the items is adequate and sufficient at a $5 \%$ significance level.

\section{Reliabilities and AVE Analysis}

The values of Cronbach's Alpha and composite reliabilities, which are over 0.65 and just approach 0.70 for all the factors, showed that the reliabilities meet the minimum criterion of threshold, i.e., 0.60. Moreover, the results of factor loading for all constructs range between $0.50-0.85$, satisfying the minimum criteria of discriminant validity (Ahmed et al., 2017). Further, the values of the average variance extracted (AVE) are more than 0.50 , thus, a condition of convergent validity is also satisfied (Fornell \& Larcker, 1981).

\section{Confirmatory Factor Analysis - CFA}

The CFA is a suitable and direct approach to structural equation modelling; we have structured a statistical model and checked through SEM analysis to see how well our model is hypothesized. If the suggested model fixes with the criterion established by the indicators of the SEM model, then amongst numerous different models, the structured model is confirmed. We examined and validated the dimensions of Islamic hire purchase through standard factor loading using AMOS 21. In the confirmatory factor analysis, we incorporated 26 items to the best fix the sample data between observed and unobserved measures (Ahmed et al., 2017). The outcomes exhibited that overall measurement model was acceptable (ranging between 0.55- 0.95), and the CFA analysis showed that factor loading for every item was greater than the value of 0.50 that substantiated the construct and convergent validities of the hypothesized model. Results of the statistics of fit indices for the measured model showed that GFI $=0.96$, $\mathrm{IFI}=0.95, \quad \mathrm{CFI}=0.96, \quad \mathrm{TLI}=0.97, \quad \mathrm{NFI}=0.94, \quad \mathrm{RNI}=0.99$, PCFI $=0.90$, PNFI $=0.87$, and RMSEA $=0.0032$, hence, all fit indices were within the prescribed limits and attained the minimum threshold level. Thus, it is concluded from the results that the considered hypothesized measured model for the Islamic hire purchase (IHP) is appropriate.

\section{Structural Qquation Modelling - SEM}

We have employed the structural model for estimation of parameters for the customers' intention to use Islamic hire purchase (IHP) in the perspective of the Islamic banking sector of Pakistan. In our structural model we used three dimensions of the TPB model such as subjective norms (SN), attitude, and PBC, three moderating variables such as religious belief (RB), pricing of Islamic products (PIP), and knowledge of Islamic products (KIP), and the intention to use Islamic hire purchase (ITU) as a dependent variable. The results of the structural model exhibited that the entire model was acceptable under the threshold values of the fit indices. The outcomes showed that the values of $\mathrm{GFI}=0.97$, $\mathrm{IFI}=0.98, \quad \mathrm{CFI}=0.97, \quad \mathrm{TLI}=0.99, \quad \mathrm{NFI}=0.96, \quad \mathrm{RNI}=0.98$, PCFI $=0.89$, PNFI $=0.88$, and RMSEA $=0.0021$ were within the prescribed limits of all indices. Moreover, Ahmed et al. (2017) concluded that if the CFI value was close to 0.95 or over, the hypothesized model should be accepted.

\section{Hypothesized Direct Relationship}

Standardized regression weights are used to interpret the direct relationship between the dimensions of the TPB model. Results of Table 1 exhibited that the T-values were greater than 2 and corresponding probabilities were less than 0.05 for all three hypotheses $\left(\mathrm{H}_{1}-\mathrm{H}_{3}\right)$. Thus, it is concluded that the dimensions of the TPB model have a cogent and positive impact on the intention to use Islamic hire purchase (ITU) financing. The individual results of $\beta$-values show that the attitude had the highest $\beta$-value of 0.613 , signifying the most dominant factor for using the Islamic hire purchase financing, and that it was followed by the PBC with 0.217 ; and then, by the subjective norm (SN) with 0.157 . 
Table 1

Hypotheses Testing Summary of Direct Relationship

\begin{tabular}{c|c|c|c|c|c|c|c|c|c|c}
\hline \multicolumn{3}{c|}{ Direct Relationship } & $\begin{array}{c}\text { Direct } \\
\text { Effect } \\
(\boldsymbol{\beta})\end{array}$ & SE & T* & P* & LLCI & ULCI & Decision \\
\hline $\mathrm{H}_{1}:$ & $\begin{array}{c}\text { Perceived } \\
\text { Behavioural } \\
\text { Control }\end{array}$ & $\rightarrow$ & $\begin{array}{c}\text { Intention to use } \\
\text { IHP }\end{array}$ & 0.217 & 0.030 & 7.160 & 0.000 & 0.157 & 0.276 & Supported \\
\hline $\mathrm{H}_{2}:$ & Attitude & $\rightarrow$ & $\begin{array}{c}\text { Intention to use } \\
\text { IHP }\end{array}$ & 0.613 & 0.022 & 28.401 & 0.000 & 0.570 & 0.655 & Supported \\
\hline $\mathrm{H}_{3}:$ & $\begin{array}{c}\text { Subjective } \\
\text { Norms }\end{array}$ & $\rightarrow$ & $\begin{array}{c}\text { Intention to use } \\
\text { IHP }\end{array}$ & 0.157 & 0.033 & 4.694 & 0.000 & 0.091 & 0.222 & Supported \\
\hline \multicolumn{8}{c}{$\begin{array}{c}\text { * Denotes T>2.00; and } \mathrm{p}<0.05 \\
\text { Source: Authors' calculations }\end{array}$}
\end{tabular}

\section{Moderation Analysis}

The results of Table 2 show that moderating variables such as knowledge of Islamic products (KIP), pricing of Islamic products (PIP), and religious belief (RB) have significant impact on the relationships of the dimensions of the TPB model (PBC, SN, attitude) and the intent to buy the Islamic hire purchase (IHP). The multiplicative effect of the PBC and moderating variables exhibited significant effects because the corresponding probabilities are less than the value of 0.05 . Hence, the null hypotheses such as $\mathrm{H}_{4 \mathrm{~A}}, \mathrm{H}_{5 \mathrm{~A}}$, and $\mathrm{H}_{6 \mathrm{~A}}$ were rejected, and the decision is in support of the statement. Similarly, the null hypotheses $\mathrm{H}_{4 \mathrm{~B}}, \mathrm{H}_{5 \mathrm{~B}}, \mathrm{H}_{6 \mathrm{~B}}$ were rejected, and it is concluded that the moderators KIP, PIP, and RB have the significant impact on the association of $\mathrm{PBC}, \mathrm{SN}$, the attitude and the intention to use IHP financing. The null hypotheses $\mathrm{H}_{4 \mathrm{C}}$, $\mathrm{H}_{5 \mathrm{C}}, \mathrm{H}_{6 \mathrm{C}}$ were also rejected $(\mathrm{p}<0.05)$; hence, the effect of the moderators KIP, PIP, and RB is also significant.

Table 2

Moderating Effect of Religious Beliefs, Knowledge of Islamic Products, and Pricing of Islamic Products

\begin{tabular}{|c|c|c|c|c|c|c|c|c|}
\hline Hypotheses & Moderators & Moderation & Coefficient & SE & $\mathbf{T}$ & $\mathbf{P}^{*}$ & LLCI & ULCI \\
\hline \multicolumn{9}{|c|}{ Moderating Effect of the RB, KIP, and PIP b/w PBC and Intention to use IHP } \\
\hline $\mathrm{H}_{4 \mathrm{~A}}:$ & $\mathrm{RB}$ & PBC $x$ RB & -0.1726 & 0.0127 & -13.64 & 0.0000 & -0.1974 & -0.1477 \\
\hline $\mathrm{H}_{5 \mathrm{~A}}:$ & KIP & PBC x KIP & -0.1891 & 0.0135 & -13.97 & 0.0000 & -0.2157 & -0.1625 \\
\hline $\mathrm{H}_{6 \mathrm{~A}}:$ & PIP & PBC x PIP & -0.0540 & 0.0190 & -2.84 & 0.0046 & -0.0913 & -0.0167 \\
\hline \multicolumn{9}{|c|}{ Moderating Effect of the RB, KIP, and PIP b/w Attitude and Intention to use IHP } \\
\hline $\mathrm{H}_{4 \mathrm{~B}}$ : & RB & Attitude $\mathrm{x}$ RB & -0.0833 & 0.0110 & -7.60 & 0.0000 & -0.1048 & -0.0618 \\
\hline $\mathrm{H}_{5 \mathrm{~B}}:$ & KIP & Attitude $\mathrm{x}$ KIP & -0.0547 & 0.0107 & -5.09 & 0.0000 & -0.0758 & -0.0336 \\
\hline $\mathrm{H}_{6 \mathrm{~B}}:$ & PIP & Attitude x PIP & 0.0977 & 0.0074 & 13.25 & 0.0000 & 0.0832 & 0.1122 \\
\hline \multicolumn{9}{|c|}{ Moderating Effect of the RB, KIP, and PIP b/w Subjective norms and Intention to use IHP } \\
\hline $\mathrm{H}_{4 \mathrm{C}}:$ & $\mathrm{RB}$ & $\mathrm{SN} \times \mathrm{RB}$ & -0.0778 & 0.0127 & -6.12 & 0.0000 & -0.1028 & -0.0528 \\
\hline $\mathrm{H}_{5 \mathrm{C}}$ : & KIP & SN x KIP & -0.1157 & 0.0135 & -8.58 & 0.0000 & -0.1422 & -0.0892 \\
\hline $\mathrm{H}_{6 \mathrm{C}}:$ & PIP & SN x PIP & 0.0478 & 0.0201 & 2.38 & 0.0177 & 0.0083 & 0.0873 \\
\hline
\end{tabular}

Note: ' $\mathrm{x}$ ' is known as the multiplicative sign; * denotes rejection of the hypotheses at 0.05 level $(\mathrm{p}<0.05)$; DV = Intention to use IHP (Islamic Hire Purchase); PBC = Perceived behavioural control; SN = Subjective norms; RB = Religious beliefs; KIP = Knowledge of Islamic products; PIP = Pricing of Islamic products Source: Authors' calculations

\section{Visualization of the Conditional Effect}

Visualisation of the conditional effect, presented in figures 2-10, in which the 3D plots exhibit that dimensions of the TPB model (PBC, SN, attitude) and the intention to use IHP, shows a significant influence of moderation, inducting three moderating variables such as KIP, PIP, RB. The results of figures 2-10 depict that the effect of the intention to use IHP financing is changing with different values of moderating variables (KIP, PIP, RB), with constant values for dimensions of the TPB model (PBC, SN, attitude). Ahmed et al. (2017) pointed out that the graphical representation was an essential condition to show the moderation process because it clearly demonstrated the impact of moderation. In figures 2-10, black colour shows the dimensions of the TPB model, light grey colour depicts incorporated moderators (KIP, PIP, RB), and grey colour exhibits the effect of the intention to use IHP financing. The 3D graphs in figures 2-10 enable to conclude that moderating variables have a cogent influence in the association of PBC, attitude, subjective norm (SN) and the use of the IHP financing facility in the context of the Islamic banking sector of Pakistan. 


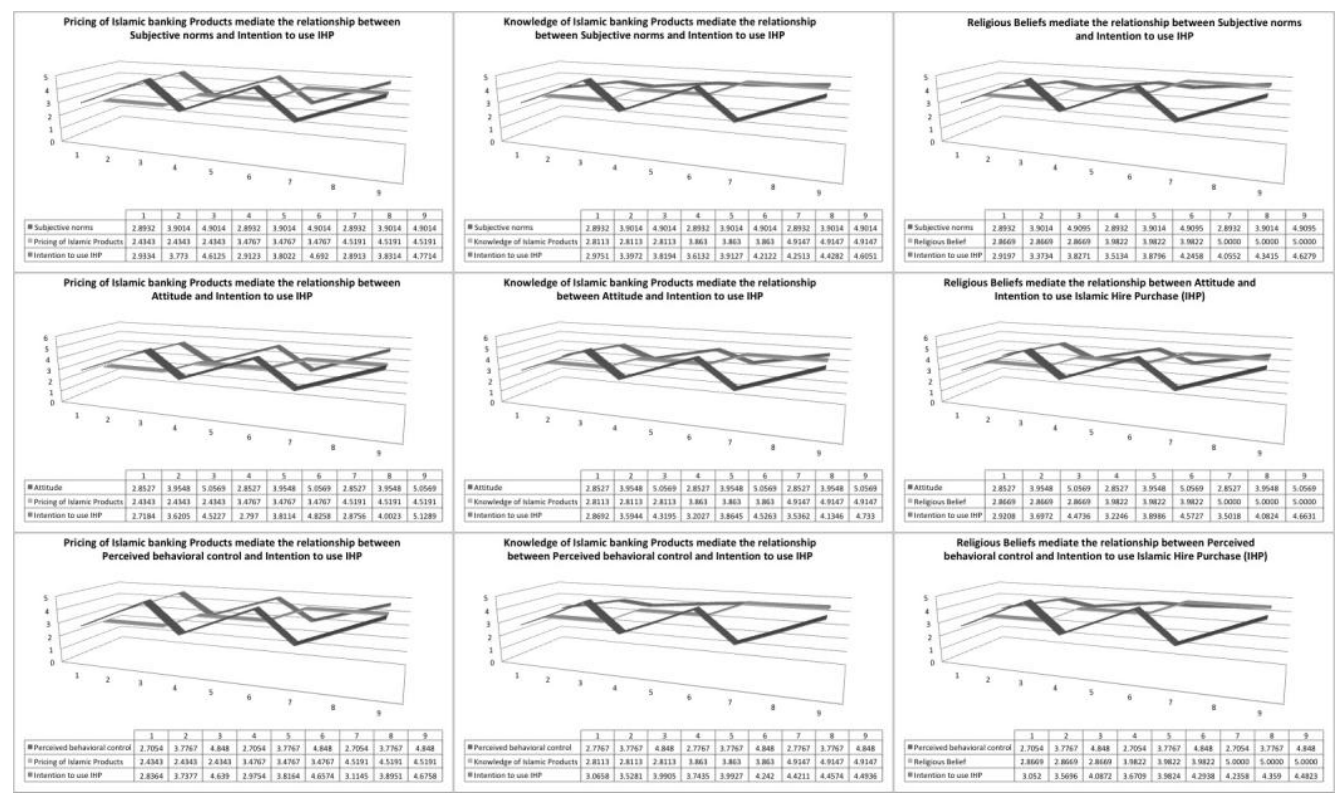

Figure 2- Figure 10. 3D plots of the Interaction between Quality Dimensions and Technology and Visualization of the Conditional Impact on Customer Satisfaction

Source: Authors' calculations

\section{Conclusions}

The outcomes of the undertaken study on customers' intention to use IHP financing are consistent with previous literature, however, provide more explanations and insights to such purchasing behaviour. Research results demonstrated that perceived behavioural control (PBC) had a more significant and positive influence on using IHP financing facility and that the least important dimension was the subjective norm (SN), which nevertheless also had an affirmative and cogent influence on using IHP financing facility. The results demonstrate that introduced three moderating variables such as knowledge of Islamic products (KIP), pricing of Islamic products (PIP), and religious belief (RB) have a significant impact on the relationships between PBC, the attitude, the subjective norm and customers' intention to use Islamic hire purchase (IHP) financing. Our findings indicate that knowledge of Islamic products (KIP) and pricing of Islamic products (PIP) are important moderating variables, significantly influencing the relationships between $\mathrm{PBC}$, the $\mathrm{SN}$, the attitude and customers' buying behaviour of Islamic hire purchase (IHP) financing facility. The outcomes of the undertaken research demonstrate that Islamic banks should enhance their promotional and advertising campaigns in order to increase awareness of their products. Besides, Islamic banks should put more emphasis on the basis of their products and educate common people that their products comply with the Shariah principles of Islam.

\section{Managerial Policy Implications}

The undertaken research provides the basis, predominantly to Islamic policy-makers and bank administrators, to make decisions and create strategies in order to increase the effectiveness of Islamic hire purchase financing. Having in minds the practical insight of this research, Islamic bank administrators should consider customers' psychological factors in order to comprehend customers' adoption for the Islamic hire purchase financing product. Additionally, aspiring the rate of customers' adoption towards Islamic hire purchase financing, some significant elements still need to be identified. This will also upgrade the current scenario for bank administrators, accepting more customers of hire purchase financing complying with Shariah law. Not only the current but also the potential purchaser of the Islamic hire purchase financing facility will increase demand for the product and support to foreseen behavioural intentions.

\section{Limitations and Future Research Directions}

The undertaken study introduced new findings and sets a novel dimension in the perspective of customers' intention to buy Islamic hire purchase (IHP) financing, although it exhibited certain limitations and delimitations: the study did not distinguish between current and potential customers of Islamic hire purchase financing, the geographic scope is limited to Karachi city. The data were collected during the working hours, which may have resulted in an error during the data collection procedure. Therefore the foreseen control of the TPB does not include personality and demographic factors in this model. Likewise, it is difficult to measure the individual's PBC, as this theory ignores the individual's unconscious motives, assuming only rational and systematic decisions.

It should be noted that our research has identified some potential and useful gaps for future research. First, this study employed the TPB model and was limited to the subjective norms, attitude, perceived behavioural control as independent variables, however, we used religious belief, knowledge of Islamic products, and pricing of Islamic products as moderating variables. Thus, any future study could be carried out by employing some other finer set of explanatory factors that can further improve the robustness of the TPB model and overall outcomes of the undertaken 
study in the perspective of IHP. These factors may include personal factors, The research should involve personal factors, features of halal products, financial commitment, and the scope of the risk.

Evidently, no impending conflict of interest was reported by the researchers.

\section{References}

Adamus, M. (2017), Reasons for Doing Good: Behavioural Explanations of Prosociality in Economics. Economics and Sociology, 10(1), 122-134. https://doi.org/10.14254/2071-789X.2017/10-1/9

Ahmed, R. R., Vveinhardt, J., \& Streimikiene, D. (2017). Exploring multidimensional view of intellectual capital and Business ethics on Organizational performance using Bootstrapping method: Evidence from Pakistani Pharmaceutical Industry. Montenegrin Journal of Economics, 13(1), 7-33. https://doi.org/10.14254/18005845/2017.13-1.1

Ahmed, R. R., Vveinhardt, J., Streimikiene, D., \& Awais, M. (2016). Mediating and Marketing factors influence the prescription behaviour of Physicians: An Empirical Investigation. Amfiteatru Economic,18(41), 153-167.

Ajzen, I. (1991). The theory of planned behaviour. Organizational Behavior and Human Decision Processes, 50(2), 179211. https://doi.org/10.1016/0749-5978(91)90020-T

Ajzen, I., \& Fishbein, M. (2000). Attitudes and the attitude-behaviour relation: reasoned and automatic processes, in: Stroebe, W. \& Hewstone, M. (Eds), European Review of Social Psychology, 1-28 (New York, NY: Wiley). https://doi.org/10.1080/14792779943000116

Akpinar, E., Peeter W. J., Verlegh, P. W. J., Smidts, A. (2018). Sharing product harm information: The effects of selfconstrual and self-relevance. International Journal of Research in Marketing, 35(2), 319-335. https://doi.org/10.10 16/j.ijresmar.2018.01.001

Ali, M., Raza, S. A., Puah, C. H., \& Karim, M. Z. A. (2017). Islamic home financing in Pakistan: A SEM-based approach using modified TPB model. Housing Studies, 32(8), 1156-1177. https://doi.org/10.1080/02673037.2017.1302079

Amin, H., Rahman, A. R. A., \& Razak, D.A. (2014). Consumer acceptance of Islamic home financing. International Journal of Housing Markets and Analysis, 7(3), 307-332. https://doi.org/10.1108/IJHMA-12-2012-0063

Anderson, J. C., \& Gerbing, D. W. (1988). Structural equation modelling in practice: a review and recommended two-step approach. Psychological Bulletin,103(3), 411-423. https://doi.org/10.1037//0033-2909.103.3.411

Bilic, B. (2005). The theory of planned behaviour and health behaviors: Critical analysis of methodological and theoretical issues. Hellenic Journal of Psychology, 2(3), 243-259.

Chan, S. C., \& Lu, M. T. (2004). Understanding Internet banking adoption and user behaviour: a Hong Kong perspective. Journal of Global Information Management, 12(3), 21-43. https://doi.org/10.4018/jgim.2004070102

Chau, P. Y., \& Hu, P. J. H. (2001). Information technology acceptance by individual professionals: A model comparison approach. Decision sciences, 32(4), 699-719. https://doi.org/10.1111/j.1540-5915.2001.tb00978.x

Chong, B. S., \& Liu, M. H. (2009). Islamic banking: Interest-free or interest-based? Pacific Basin Finance Journal, 17, 125-144. https://doi.org/10.1016/j.pacfin.2007.12.003

Cismaru, I., Petrescu, I., Dragomir, C., Cismaru. L. (2017). Commission airing System Internationalisation: Certainty Vector in Sustainable Development. Transformations in Business \& Economics, 16, No 1 (40), 52-69. https://doi.org/10.1353/rmr.1986.0021

Collins, R. L., \& Ellickson, P. L. (2004). Integrating four theories of adolescent smoking. Substance Use \& Misuse, 39(2), 179-209. https://doi.org/10.1081/JA-120028487

Compeau, D. R., \& Higgins, C. A. (1995). Computer self-efficacy: development of a measure and initial test, MIS Quarterly, 19(2), pp. 189-211. https://doi.org/10.2307/249688

Davis, F. D., Bagozzi, R. P., \& Warshaw, P. R. (1989). User acceptance of computer technology: a comparison of two theoretical models. Management Science, 35(8), 982-1003. https://doi.org/10.1287/mnsc.35.8.982

Dusuki, A. W., \& Abdullah, N. I. (2007). Why Do Malaysian Customers Patronise Islamic Banks? International Journal of Bank Marketing, 25(3), 142-160. https://doi.org/10.1108/02652320710739850

Ercsey I. (2017). The role of customers' involvement in value co-creation behaviour: is value co-creation the source of competitive advantage? Journal of Competiveness, 9 (3), 51-65. https://doi.org/10.7441/joc.2017.03.04

Fishbein, M., \& Yzer, M. C. (2003). Using theory to design effective health behaviour interventions. Communication theory, 13(2), 164-183. https://doi.org/10.1111/j.1468-2885.2003.tb00287.x

Fornell, C., \& Larcker, D. F (1981). Evaluating structural equation models with unobservable variables and measurement error. Journal of Marketing Research, 39, 39-50. https://doi.org/10.1177/002224378101800104 
Rizwan Raheem Ahmed, Jolita Vveinhardt, Dalia Streimikiene, Vaida Pilinkiene. Application of the Theory of Planned...

Gavurova, B., Bacik, R., Fedorko, R., Nastisin, L. (2018). The customer's brand experience in the light of selected performance indicators in the social media environment. Journal of Competitiveness, 10 (2), $72-84$. https://doi.org/10.7441/joc.2018.02.05

Gerrard, P., \& Cunningham, J. B. (1997). Islamic banking: a study in Singapore. International Journal of Bank Marketing, 15(6), 204-216. https://doi.org/10.1108/02652329710184433

Greve, W. (2001). Traps and gaps in action explanation: Theoretical problems of a psychology of human action. Psychological review, 108(2), 435-436. https://doi.org/10.1037//0033-295X.108.2.435

Haron, S., Ahmed, N., \& Planisek, S. (1994). Bank patronage factors of Muslims and non-Muslim customers. International Journal of Bank Marketing, 12(1), 32-40. https://doi.org/10.1108/02652329410049599

Kaiser, H.F. (1974). An index of factorial simplicity. Psychometrika, 39(1), 31-36. https://doi.org/10.1007/BF02291575

Karbowski, A. (2016), Discussion on the Social Rate of Discount: from Sen to Behavioural Economics. Economics and Sociology, 9(2), 46-60. https://doi.org/10.14254/2071-789X.2016/9-2/3

Metawa, S. A., \& Al-Mossawi, M. (1998). Banking Behaviour of Islamic Bank Customers: Perspectives and Implications. International Journal of Bank Marketing, 16(7), 299-313. https://doi.org/10.1108/02652329810246028

Muthiah, K., Suja, S. (2017). A Study on Sense, Feel, Think, Act, Relate Factors of Experiential Marketing in Retailing. Transformations in Business \& Economics, 16, No 1 (40), 85-100.

Naser, K., Jamal, A., \& Al-Khatib, K. (1999). Islamic Banking: A Study of Customer Satisfaction and Preferences in Jordan. International Journal of Bank Marketing, 17(3), 135-150. https://doi.org/10.1108/02652329910269275

Novak, P., Dvorsky, J., Popesko, B., \& Strouhal, J. (2017). Analysis of overhead cost behaviour: case study on decisionmaking approach. Journal of International Studies, 10(1), 74-91. https://doi.org/10.14254/2071-8330.2017/10-1/5

Prapavessis, H., Gaston, A., Stefanie DeJesus, S. (2015). The Theory of Planned Behavior as a model for understanding sedentary behavior. Psychology of Sport and Exercise, 19, 23-32. https://doi.org/10.1016/j.psychsport.2015.02.001

Shih, Y.Y., \& Fang, K. (2004). The use of decomposed theory of planned behaviour to study Internet banking in Taiwan. Internet Research, 14(3), 213-223. https://doi.org/10.1108/10662240410542643

Tseng M.L., Lan, L.W., Wang, R., Chiu, A. S. F., \& Cheng, H. P. (2011). Using hybrid model to evaluate the green performance in uncertainty. Environmental Monitoring and Assessment, 175(1), 367-385. https://doi.org/10.100 7/s10661-010-1537-x

Varanavicius, V., Navikaite, A., Bilan, Y., B., \& Strielkowski, W. (2017). Analysis of consumer behaviour in regional energy consumption. Ekonomika regiona-economy of region, 13(1), 147-156 https://doi.org/10.17059/2017-1-14

Wilkinson, D., \& Abraham, C. (2004). Constructing an integrated model of the antecedents of adolescent smoking. British Journal of Health Psychology, 9(3), 315-333. https://doi.org/10.1348/1359107041557075

The article has been reviewed.

Received in September 2018; accepted in April 2019. 